\title{
Technology Foresight: A Bibliometric Analysis to Identify Leading and Emerging Methods
}

\author{
Elizabeth Gibson ${ }^{\text {a }}$ \\ Professor, eliz.gibson@colorado.edu \\ Tugrul Daim ${ }^{\text {b }}$ \\ Professor, and Director of Technology Management Doctoral Program, tugrul.u.daim@pdx.edu \\ Edwin Garces ${ }^{b}$ \\ Ph.D Student, edwing@pdx.edu \\ Marina Dabic c,d \\ Professor, marina.dabic@ntu.ac.uk \\ ${ }^{\text {a }}$ University of Colorado at Boulder, Boulder CO 80309 USA \\ ${ }^{\mathrm{b}}$ Portland State University, 1900 SW 4th Avenue, LL, Suite 50-02, Portland OR 97201 USA \\ ${ }^{c}$ Nottingham Trent University, 50 Shakespeare St, Nottingham NG1 4FQ, UK \\ ${ }^{d}$ University of Zagreb, Trg J.F. Kennedyja 6, Zagreb 10 000, Croatia
}

\begin{abstract}
$\mathrm{F}$ oresight studies provide essential information used by the government, industry and academia for technology planning and knowledge expansion. They are complicated, resource-intensive, and quite expensive. The approach, methods, and techniques must be carefully identified and selected. Despite the global importance of foresight activities, there are no frameworks to help one develop and plan a proper foresight study. This paper begins

to close this gap by analyzing and comparing different schools of thought and updating the literature with the most current tools and methods. Data mining techniques are used to identify articles through an extensive literature review. Social Network Analysis (SNA) techniques are used to identify and analyze leading journals, articles, and researchers. A framework is developed here to provide a guide to help in the selection of methods and tools for different approaches.
\end{abstract}

Keywords: technology foresight; strategic foresight; adaptive foresight; Social Network Analysis (SNA); bibliometric tools; data mining; text mining.

Article type: research paper
Citation: Gibson E., Daim T., Garces E., Dabic M. (2018) Technology Foresight: A Bibliometric Analysis to Identify Leading and Emerging Methods. Foresight and STI Governance, vol. 12, no 1, pp. 6-24. DOI: 10.17323/25002597.2018.1.6.24 
$\mathrm{T}$ echnology foresight is a process that systematically looks into the future to examine areas of research and emerging technologies [Grupp, Linstone, 1999]. The results of this process provide inputs for policy setting and strategic planning [Alsan, Oner, 2003; Major et al., 2001]. Foresight studies are increasingly important as policy makers grapple with complex socio-technical challenges in major industries, such as information and communication technology (ICT) [Rohrbeck, 2010], energy, food [Chavez, 2013], healthcare [Masum et al., 2010], and transportation [Alkemade, Suurs, 2012]. They are often expensive and time-consuming. However, conducting effective and efficient technology foresight studies remains a challenge. Technologies, as well as the methods, techniques, and tools used to examine them, are evolving rapidly. Thus, the process previously used may no longer deliver the best results. Different approaches, tools, and methods add to the complexity. Despite the global importance of foresight activities, the literature lacks consensus about the approach, methods, tools, and techniques required to conduct foresight activities [Blind et al., 1999]. This paper synthesizes technology foresight research and introduces a framework that can be used by policy makers as a guide for designing and conducting a proper foresight study.

The literature shows that many studies have been conducted for a variety of purposes. The European Network for Monitoring Technology Foresight (EFMN) recognizes 73 different foresight activities in Europe, 120 in South America, 109 in North America, 89 in Asia, and 15 in regions of Australia and Oceania [European Commission, 2009]. Among these, 67 international projects have been financed by the OECD (Organization for Economic Co-operation and Development), FAO (Food and Agriculture Organization of the United Nations), UNESCO (United Nations Educational, Scientific, and Cultural Organization), UNIDO (United Nations Industrial Development Organization), and World Bank. While most of these studies have been conducted to provide inputs into policy setting, other reasons include strategic planning, decision support for priority setting, infrastructure decisions [Ecken et al., 2011], or the pursuit of knowledge [Yokoo, Okuwada, 2013].

Two literature reviews were conducted to examine the importance, methods, and techniques used and challenges found when conducting technology foresight studies. First, "foresight" was used as a keyword to search three major indices (Science Citation Index Expanded, Social Sciences Citation Index and Humanities Citation Index) between the years 1980-2013 to select journal articles. Figure 1 represents a trend of increased popularity since the early 1990s. A content review of the abstracts supports the EFMN data and provides evidence that studies are increasingly being undertaken for broader purposes.

An integrated bibliometric approach with a two-step social network analysis process was developed to systematically uncover the dynamics and contextual relationships. Specifically, Step 1 informed Step 2 and the results out of Step 2 were integrated into the interpretation of the literature. Further content analysis was used to develop and then apply a framework to discuss the results and finalize the paper.

Today, not only is it imperative to be knowledgeable about current methods and trends, it is also important to select the techniques that best support the purpose of the study. However, the evolution of foresight methodology is diverse, resulting in confusion about selecting the proper approach and techniques for a given time period [Choi, Park, 2009]. Thus, a more systematic and robust review of the literature was conducted to describe the methodological landscape of foresight used and studied around the world. A three-phase framework was developed. Five criteria were used to map methods into the framework resulting in a decision-support model for selecting methods required to conduct a proper foresight study.

\section{Background}

As World War II came to a close, policy leaders began to recognize the importance of science and technology as inputs for foresight studies. The energy crisis, of the 1970s and 1980s, required foresight studies to consider further inputs such as the political, geopolitical, and enconomic environment. Irvine and Martin [Martin, 2010] began to consistently use and apply technology foresight terminology in studies for "futures" work funded by the Office of Technology Assessment (OTA) [Miles, 2010]. Martin defined foresight as a "process involved in systematically attempting to look into the longer-term future of science, technology, the economy and society with the aim of identifying the areas of strategic research and the emerging generic technologies likely to yield the greatest economic and social benefits" [Martin, Johnston, 1999]. Other researchers [Bezold, 2010] expanded upon this definition in an attempt to gain definitional consensus in the field.

Many nations undertake periodic foresight activities for national policy setting [Georghiou et al., 2014]. Grupp and Linstone noted the importance of foresight as a national policy tool to "wire-up" and strengthen national innovation programs [Grupp, Linstone, 1999]. Cuhls [Cuhls, 2003] emphasized that foresight is a process rather than a set of tools, stressing the importance of communication. This led researchers to the concept of multiple futures. In Germany, Futur was typically recognized as a continuous process characterized by features such as multiple perspectives and an orientation towards society's needs at the national level [Ibid.]. In parallel, researchers in France clarified similar concepts using the term la prospective [Coates et al., 2010]. In the UK, foresight panels explored how market drivers would shift as the aging population became more techno-friendly and demanded a higher quality life [DTI, 2000]. 


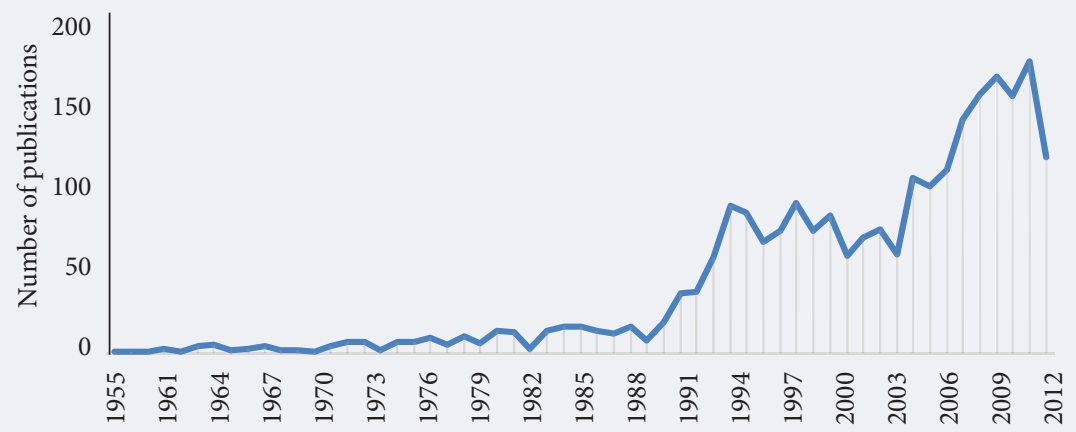

Source: compiled by the authors.

The 1990s and 2000s introduced even more complexity and resulted in more political, socital, psychological, and cultural factors to be considered when gathering foresight study inputs. Data was included to consider the citizens' perspective about the environment and technology. Today, systematic efforts are used to collect data that will provide a holistic picture required to examine the future interactions of science, technology, society, and the economy to promote and exploit social, economic, and environmental benefits [Cachia et al., 2007].

Policymakers are interested in measuring the impact of these studies because they are expensive and time consuming. The European Foresight Network states that "a participative approach to creating shared longterm visions to inform short-term decision-making processes" [Calof, Smith, 2012, p. 5] as their primary purpose for funding a foresight study. This shift in purpose spurred interest by connecting science and technology to societal problems. Martin and Johnson found that technology foresight provided: 1) an approach for science and technology policy decision making, 2) offered a way to integrate research opportunities and link science and technology to wealth creation, and 3) stimulated communication between necessary stakeholders for translational research [Martin, Johnston, 1999].

National planners and corporate strategists are both concerned about the examination of multiple futures as well as a plan for how to reach a desired future. Foresight activities are spanning countries as global companies and public-private partnerships have increased the use of foresight activities [Durand, 2003]. The Foresight Vehicle Initiative, a sub-group of the UK Foresight Programme, was launched in 1997 as a collaborative effort between the government, industry, and academia in the UK to examine possible futures of the transportation industry [Phaal, 2002]. The domain is broad, foresight studies are complex, and technology is driving improvement in the tools and methods.

\section{Methodology}

Bibliometrics and Social Network Analysis (SNA) techniques were used to develop a two-mode network. Bibliometric techniques are often used to obtain inputs for developing public policy, science programs, and technological foresight activities [Godin, 1998]. Bibliometrics are used to analyze elements such as citations, authors, and semantic items of all forms of written communication regardless of discipline or research field. Mining bibliometric patent citation data and conducting SNA has been used in foresight activities to analyze technology development trends [Choi, Park, 2009]. Graphically presenting the bibliographic data in the form of network maps is a powerful technique for knowledge transfer facilitating group discussion [Chen, Kien Pham, 2014]. Affiliated networks using SNA techniques were first used to analyze patent and citation data from the USPTO [Chien, Weng, 2012]. Incorporating keywords into the maps adds value in new technology creation activities [Lee et al., 2009]. Thus, SNA opens the opportunity for analyzing studies about technology and their relationships [Cachia et al., 2007]. This study follows the affiliated network approach by using a three-phase research approach to build a two-mode network.

One hundred ninety-six articles were selected by mining the Compendex database, from 1995 to 2015 inclusively, using the keyword "foresight". A content analysis of the literature was conducted to review the origin, purpose, and scope. Then, Social Network Analysis (SNA) was conducted to quantitatively and qualitatively analyze and investigate the social structures between journals and keywords. The framework in Figure 2 shows the three-phase approach: 1) Keyword identification via text mining, 2) Mode one analysis, 3 ) Mode two analysis.

The process of text mining was used to identify key concepts that were meaningful and representative of the topic. The analysis followed an affiliation network relationship between actors based on their participation in events. These types of networks are composed of sets of actors and subsets of events. A two-mode network allows for an analysis of the relationships among actors from two perspectives 


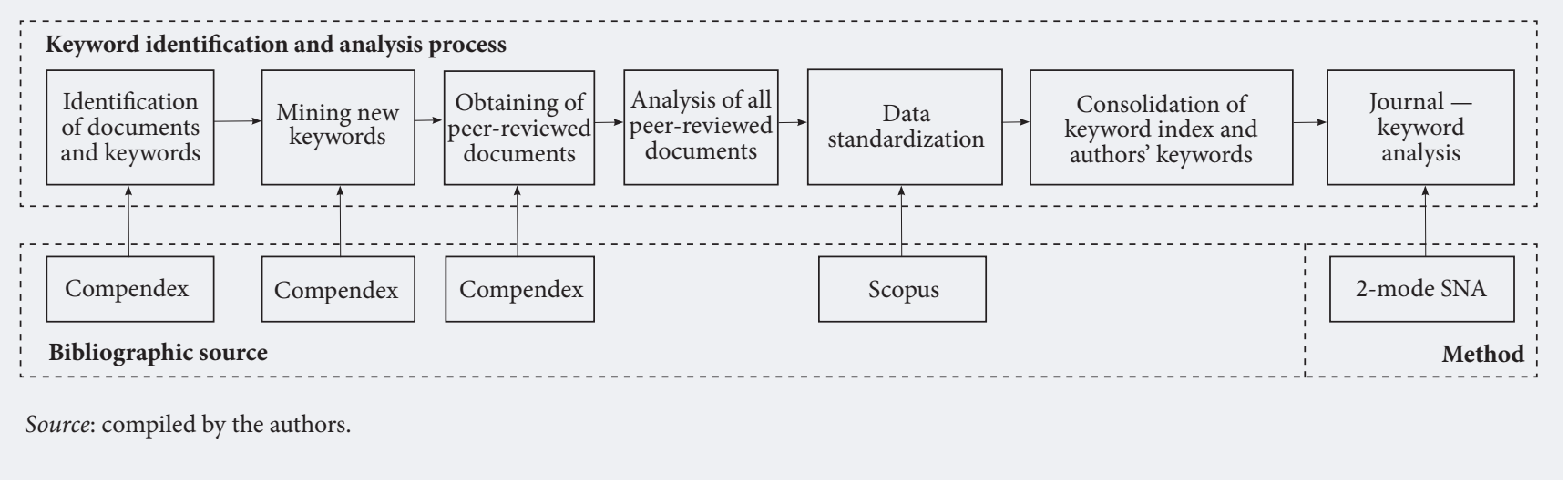

or two different single-mode events [Chien, Weng, 2012]. Thus, SNA was used to identify key concepts, leading journals, and popular methods in technology foresight.

Early researchers described a successful foresight process in terms of three simple phases: inputs, foresight activities, and outputs [Horton, 1999]. The three-stage framework, pre-foresight, foresight, and post-foresight was first documented by Irvine and Martin [Irvine, Martin, 1984]. In this context, inputs are the collection, collation, and summarization of data. Activities and skills are used in the foresight phase to produce outputs such as tools, workshops, and reports. Amsteus uses the classifications of the present situation, plan, and goal [Amsteus, 2011a]. Still other researchers have developed frameworks to fit particular case studies [Brandes, 2009] or to provide general frameworks by industry area [Boretos, 2011]. Smith and Saritas illustrated mapping foresight methods into yet another framework where Phase 1 would contain understanding, Phase 2 would consist of Synthesis, Analysis, and Transformation and Phase 3 would consist of actions [Smith, Saritas, 2011].

For this paper, the groups and keywords were synthesized and mapped into a three-phase, six-step foresight framework.

Phase 1: INITIATE

1) Define, develop, and document the purpose

2) Expected outputs, outcomes, and impact

3) Structure and approach

\section{Phase 2: EXECUTE}

4) Invite the right experts

5) Gather data

6) New methods/Innovative Analysis Techniques

\section{Phase 3: CLOSE and COMMUNICATE}

\section{Results}

The two-mode network links key concepts to journals showing a singularly directed flow. Figure 3 graphically represents how the network relates 15 journals and 1,299 key concepts. Note that three isolated journals are not considered in this analysis because they are not connected to any key concept. Figure 3 illustrates the groupings of sub-networks around important journals. When the key concepts were associated with two or more journals at the same time they were treated as common elements and are denoted by bridges linking the journals to the topics. In-degree centrality quantifies key concepts, which are graphically represented by the size of the label. The dominant journal, Technological Forecasting and Social Change, has the largest label in Figure 3 and the highest value in Table 2 because it publishes the greatest number of articles examining foresight concepts and covers the maximum array of such concepts.

Tables 1 and 2 rank the key concepts and journals. In Table 1, the centrality measures are normalized values for the two-mode network. Degree, eigenvector, closeness, and betweenness-centrality measure concepts for the positive strength of the relationship. A betweenness-centrality threshold of 0.003 was used to truncate the outliers with little interconnection between journals.

Table 2 applies the same method to quantify the importance of the journals and then ranks them using the betweenness-centrality measure.

Figure 4 shows how journals use key concepts to connect in order to form sub-networks. Table 3 shows the most cited articles on technology foresight. 
Table 1. Network Centrality Measure for Key Concepts

\begin{tabular}{|c|c|c|c|c|c|}
\hline No. & Key Concepts & Degree & Eigenvector & Closeness & Betweenness \\
\hline 1 & Decision Making & 0.600 & 0.039 & 0.936 & 0.034 \\
\hline 2 & Innovation & 0.533 & 0.039 & 0.922 & 0.019 \\
\hline 3 & Foresight & 0.400 & 0.038 & 0.904 & 0.018 \\
\hline 4 & Research & 0.467 & 0.039 & 0.903 & 0.017 \\
\hline 5 & Competition & 0.333 & 0.034 & 0.828 & 0.015 \\
\hline 6 & Societies and Institutions & 0.400 & 0.036 & 0.859 & 0.011 \\
\hline 7 & Sustainable Development & 0.333 & 0.037 & 0.882 & 0.011 \\
\hline 8 & Decision Makers & 0.200 & 0.032 & 0.807 & 0.010 \\
\hline 9 & Investments & 0.267 & 0.034 & 0.850 & 0.010 \\
\hline 10 & Social Network & 0.200 & 0.034 & 0.821 & 0.010 \\
\hline 11 & Technology Foresight & 0.333 & 0.037 & 0.876 & 0.009 \\
\hline 12 & Adaptive Foresight & 0.133 & 0.032 & 0.788 & 0.008 \\
\hline 13 & Social Aspects & 0.333 & 0.035 & 0.847 & 0.008 \\
\hline 14 & Strategic Planning & 0.333 & 0.036 & 0.852 & 0.008 \\
\hline 15 & Strategic Foresight & 0.267 & 0.034 & 0.838 & 0.007 \\
\hline 16 & Industry & 0.267 & 0.034 & 0.821 & 0.006 \\
\hline 17 & Nanotechnology & 0.267 & 0.035 & 0.855 & 0.006 \\
\hline 18 & Corporate Strategy & 0.267 & 0.036 & 0.854 & 0.005 \\
\hline 19 & Energy Market & 0.133 & 0.032 & 0.802 & 0.005 \\
\hline 20 & Energy Modeling & 0.133 & 0.032 & 0.802 & 0.005 \\
\hline 21 & Mathematical Models & 0.133 & 0.032 & 0.802 & 0.005 \\
\hline 22 & Optimization & 0.133 & 0.032 & 0.802 & 0.005 \\
\hline 23 & Planning & 0.267 & 0.037 & 0.861 & 0.005 \\
\hline 24 & Strategic Approach & 0.267 & 0.035 & 0.824 & 0.005 \\
\hline 25 & Business Development & 0.267 & 0.035 & 0.830 & 0.004 \\
\hline 26 & Business Model & 0.200 & 0.035 & 0.824 & 0.004 \\
\hline 27 & Delphi Method & 0.200 & 0.035 & 0.843 & 0.004 \\
\hline 28 & Emerging Technologies & 0.200 & 0.034 & 0.840 & 0.004 \\
\hline 29 & Industrial Research & 0.200 & 0.034 & 0.826 & 0.004 \\
\hline 30 & Research and Development Management & 0.267 & 0.035 & 0.829 & 0.004 \\
\hline 31 & Risk Management & 0.200 & 0.035 & 0.843 & 0.004 \\
\hline 32 & Technological Forecasting & 0.267 & 0.035 & 0.829 & 0.004 \\
\hline 33 & Technology & 0.267 & 0.034 & 0.819 & 0.004 \\
\hline 34 & Biotechnology & 0.200 & 0.034 & 0.818 & 0.003 \\
\hline 35 & Business Models & 0.200 & 0.033 & 0.798 & 0.003 \\
\hline 36 & Economic and Social Effects & 0.200 & 0.034 & 0.817 & 0.003 \\
\hline 37 & Evaluation & 0.200 & 0.035 & 0.831 & 0.003 \\
\hline 38 & Forecasting & 0.200 & 0.035 & 0.831 & 0.003 \\
\hline 39 & Impact & 0.200 & 0.035 & 0.831 & 0.003 \\
\hline 40 & Information Technology & 0.200 & 0.034 & 0.818 & 0.003 \\
\hline 41 & Innovation Management & 0.200 & 0.033 & 0.798 & 0.003 \\
\hline 42 & Internet & 0.200 & 0.034 & 0.817 & 0.003 \\
\hline 43 & Knowledge & 0.200 & 0.036 & 0.850 & 0.003 \\
\hline 44 & Learning & 0.200 & 0.036 & 0.850 & 0.003 \\
\hline 45 & Policy Making & 0.200 & 0.036 & 0.850 & 0.003 \\
\hline 46 & Public Policy & 0.200 & 0.034 & 0.817 & 0.003 \\
\hline 47 & Research and Development & 0.200 & 0.036 & 0.850 & 0.003 \\
\hline 48 & Scenario & 0.200 & 0.036 & 0.850 & 0.003 \\
\hline 49 & Scenarios & 0.200 & 0.036 & 0.850 & 0.003 \\
\hline 50 & Technological Development & 0.267 & 0.035 & 0.823 & 0.003 \\
\hline 51 & Technology Forecasting & 0.200 & 0.034 & 0.818 & 0.003 \\
\hline 52 & Technology Policy & 0.200 & 0.035 & 0.834 & 0.003 \\
\hline 53 & Technology Transfer & 0.200 & 0.034 & 0.817 & 0.003 \\
\hline
\end{tabular}




\section{Table 2. Journals' Network Centrality Measures}

\begin{tabular}{|l|l|c|c|c|c|}
\hline No. & \multicolumn{1}{|c|}{ Journal } & Degree & Eigenvector & Closeness & Betweenness \\
\hline 1 & Technological Forecasting and Social Change & 0.736 & 0.994 & 0.659 & 0.907 \\
\hline 2 & Foresight & 0.082 & 0.045 & 0.354 & 0.101 \\
\hline 3 & Futures & 0.091 & 0.071 & 0.359 & 0.089 \\
\hline 4 & Technovation & 0.055 & 0.034 & 0.350 & 0.065 \\
\hline 5 & Research Policy & 0.048 & 0.030 & 0.348 & 0.057 \\
\hline 6 & Energy & 0.032 & 0.009 & 0.336 & 0.050 \\
\hline 7 & Research Technology Management & 0.030 & 0.021 & 0.342 & 0.033 \\
\hline 8 & Journal of Forecasting & 0.038 & 0.033 & 0.344 & 0.031 \\
\hline 9 & International Journal of Technology Management & 0.021 & 0.011 & 0.330 & 0.026 \\
\hline 10 & Energy Policy & 0.014 & 0.007 & 0.336 & 0.017 \\
\hline 11 & International Journal of Research in Marketing & 0.011 & 0.002 & 0.313 & 0.017 \\
\hline 12 & Expert Systems with Applications & 0.010 & 0.004 & 0.332 & 0.015 \\
\hline 13 & Technology Analysis and Strategic Management & 0.015 & 0.013 & 0.326 & 0.012 \\
\hline 14 & Long Range Planning & 0.015 & 0.013 & 0.331 & 0.010 \\
\hline 15 & Journal of Service Research & 0.004 & 0.001 & 0.287 & 0.006 \\
\hline Source: compiled by the authors. & & & \\
\hline
\end{tabular}

Figure 5 focuses on the results from Figure 4 for Technological Forecasting and Social Change (TFSC) alone.

The analysis of the two-mode networks has been completed, having found the most important journals and keywords. In the case of "Decision Making" and "Innovation", these keywords are related, as have most of the other keywords, to the journal of Technological Forecasting and Social Change. After applying an ego-network option (e.g. [DeJordy, Halgin, 2008]), it can be seen that "Decision Making" and "Innovation" are common nodes between nine of the journals. Figures 6 and 7 shows the ego networks of the main keywords directly associated with technology foresight: "Decision Making", "Technological Foresight", "Adaptive Foresight", and "Strategic Foresight". In Figure 7, knowing that the journal Technological Forecasting and Social Change is associated with most of the important keywords, this journal was removed in order to have more clear idea of the ego-networks directly associated with technology foresight.

\section{Figure 3. SNA Network of Journals and Keywords}

Journal of Service Research
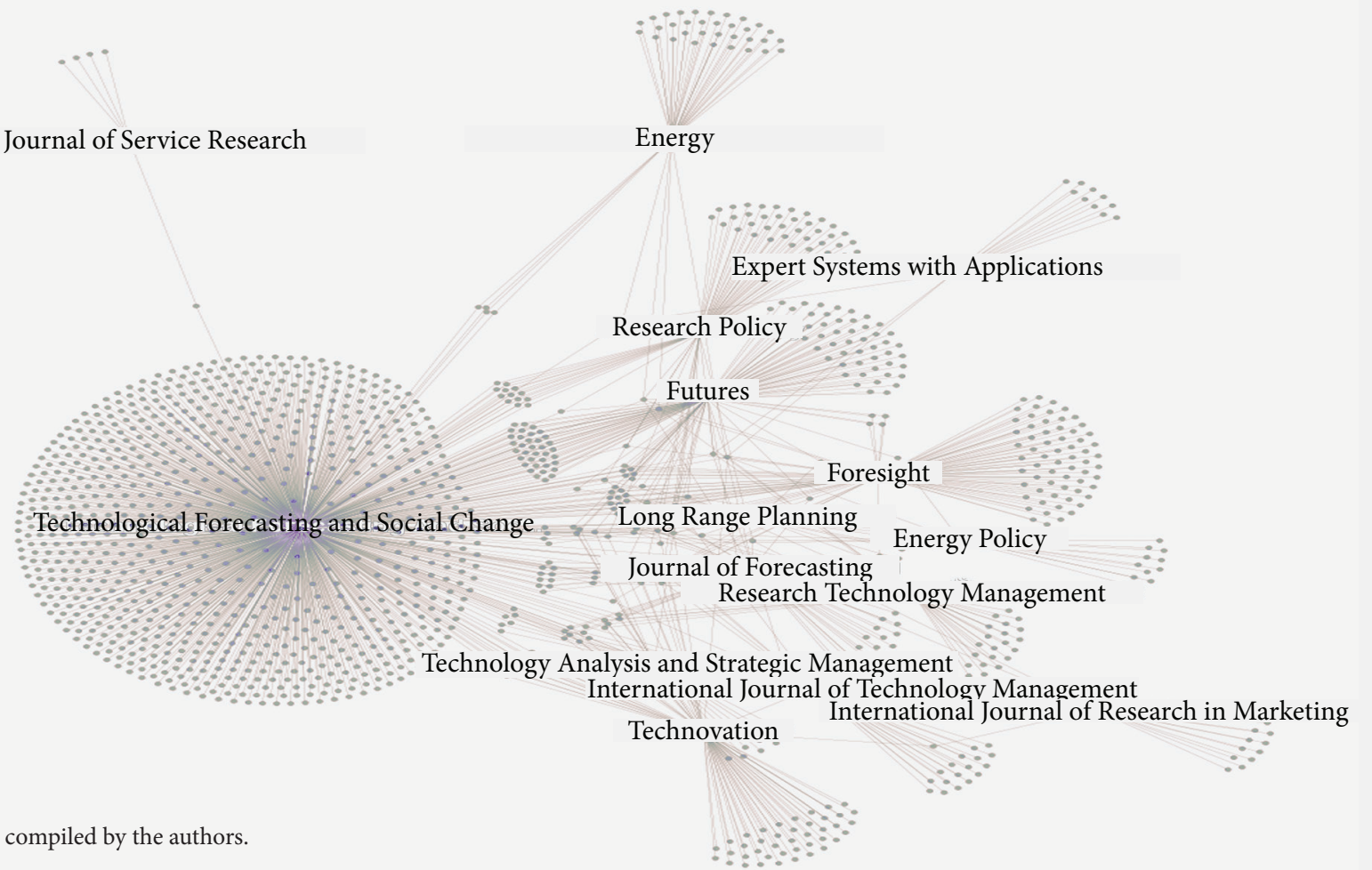

Source: compiled by the authors. 


\section{Figure 4. SNA Sub-Networks of Journals and Keywords}

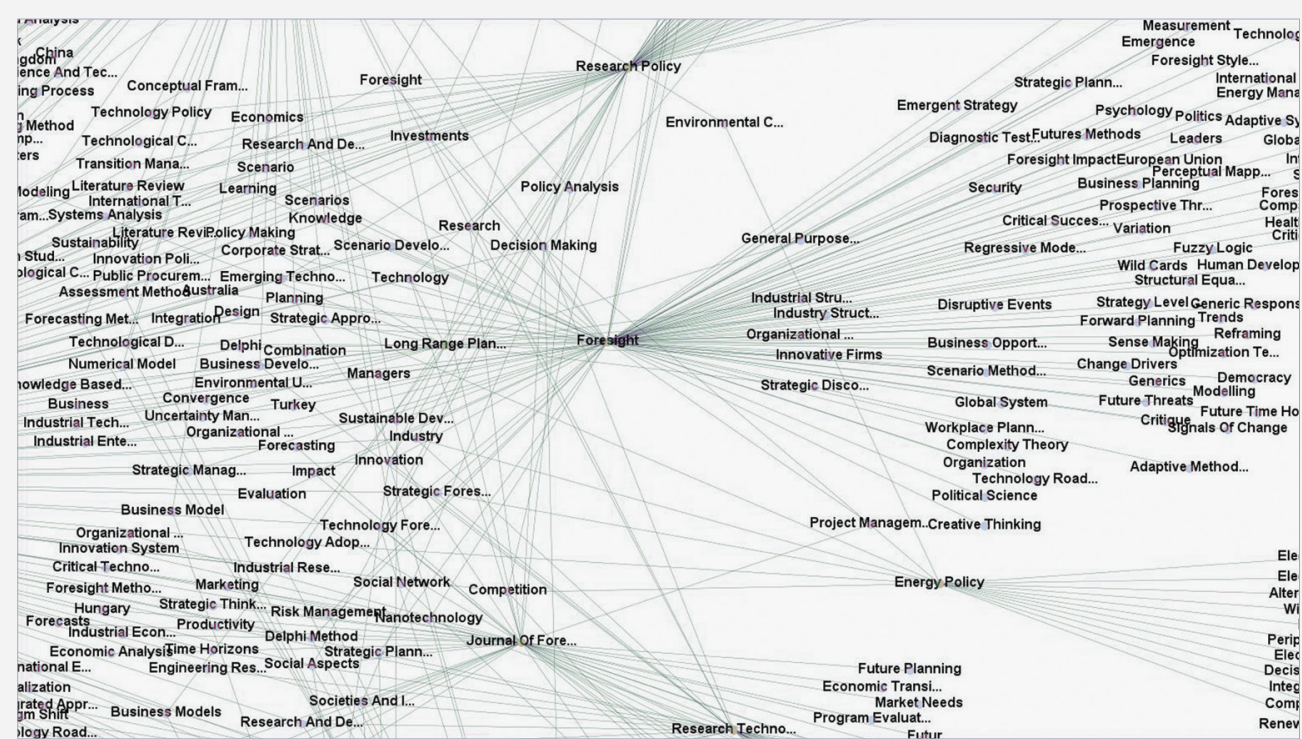

Source: compiled by the authors.

It can be seen in Figure 7 that the keywords "Technological Foresight' are associated with the journal Foresight with a high betweennees level and are associated with the keyword "Strategic Foresight". "Adaptive Foresight" is associated to two journals. One is the Journal of Service Research, which is not associated with any other important keywords. The keyword "Strategy Foresight" is linked to three important journals, two of them directly associated with technology management with connections to the keyword "Technology Foresight". Following the strategy of analyzing ego-networks directly associated with technology foresight, the ego-network of the journal Foresight is shown in Figure 8. The journal Foresight links many important keywords including "strategic planning", "decision making", "innovation", and "strategic foresight". All of the keywords linked to the journal Foresight are associated simultaneously with a high number of important journals.

\section{Figure 5. TFSC Connections to Other Journals}

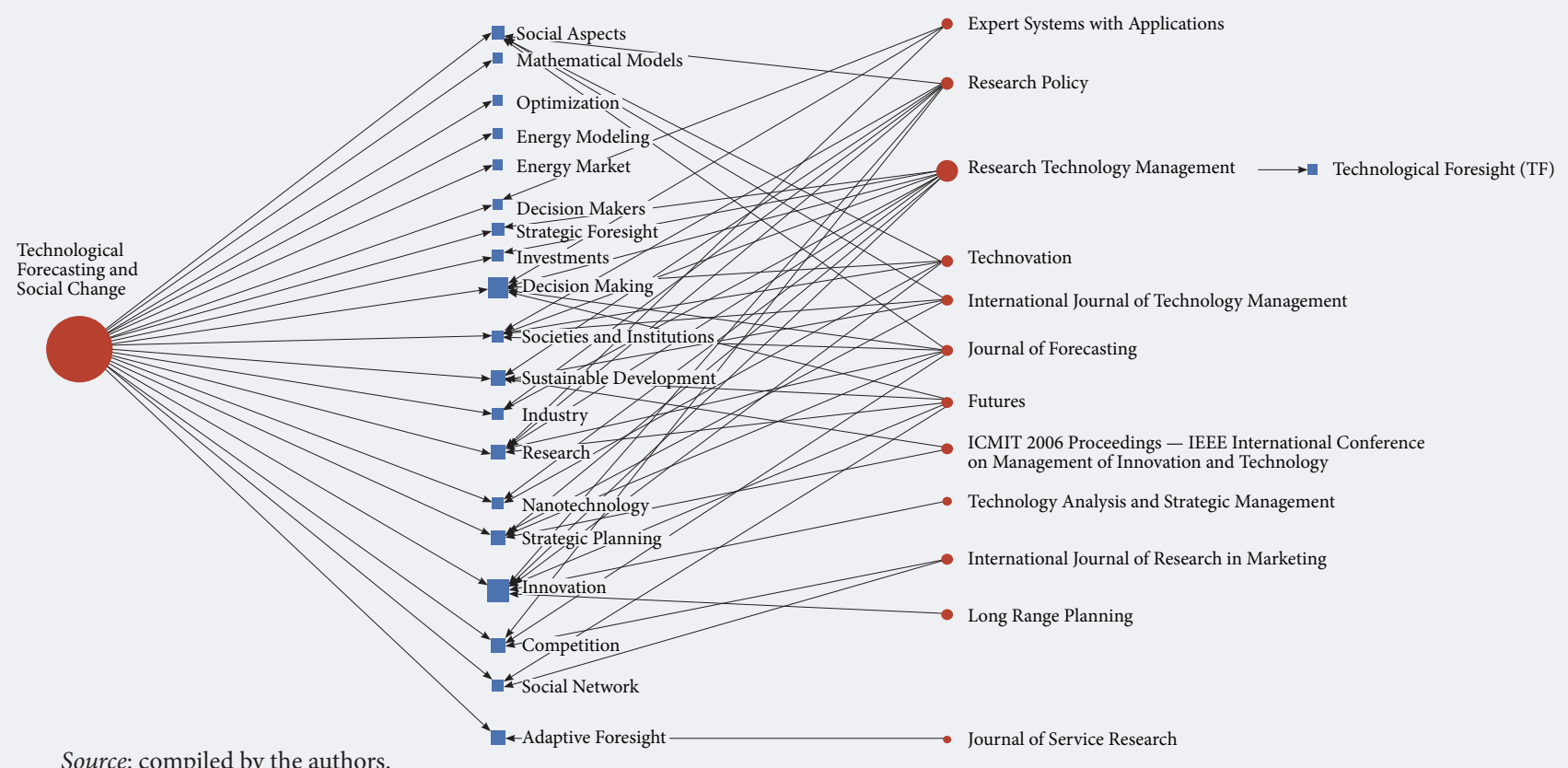




\section{Table 3. Most Cited Articles on Technology Foresight}

\begin{tabular}{|c|c|c|c|c|c|}
\hline Author(s) & Title & Journal & Citations & Year & Reference \\
\hline Robert Phaal et al. & $\begin{array}{l}\text { Technology roadmapping - } \\
\text { A planning framework for } \\
\text { evolution and revolution }\end{array}$ & $\begin{array}{l}\text { Technological Forecasting } \\
\text { and Social Change }\end{array}$ & 273 & 2004 & $\begin{array}{l}\text { [Phaal et al., } \\
\text { 2004] }\end{array}$ \\
\hline Jules Pretty et al. & $\begin{array}{l}\text { Sustainable intensification in } \\
\text { African agriculture }\end{array}$ & $\begin{array}{l}\text { International Journal of } \\
\text { Agricultural Sustainability }\end{array}$ & 191 & 2011 & $\begin{array}{l}\text { [Pretty et al., } \\
\text { 2011] }\end{array}$ \\
\hline Anthony van Raan & $\begin{array}{l}\text { Advanced bibliometric } \\
\text { methods as quantitative core of } \\
\text { peer review based evaluation } \\
\text { and foresight exercises }\end{array}$ & Scientometrics & 180 & 1996 & $\begin{array}{l}\text { [van Raan, } \\
\text { 1996] }\end{array}$ \\
\hline Andrew Maynard & $\begin{array}{l}\text { Nanotechnology: The next } \\
\text { big thing, or much ado about } \\
\text { nothing? }\end{array}$ & $\begin{array}{l}\text { Annalysis of Occupational } \\
\text { Hygiene }\end{array}$ & 163 & 2007 & $\begin{array}{l}\text { [Maynard, } \\
\text { 2007] }\end{array}$ \\
\hline $\begin{array}{l}\text { William McDowall } \\
\text { and Malcolm } \\
\text { Eames }\end{array}$ & $\begin{array}{l}\text { Forecasts, scenarios, visions, } \\
\text { backcasts and roadmaps to the } \\
\text { hydrogen economy: } \\
\text { A review of the hydrogen } \\
\text { futures literature }\end{array}$ & Energy Policy & 158 & 2006 & $\begin{array}{l}{[\text { McDowall, }} \\
\text { Eames, 2006] }\end{array}$ \\
\hline Jules Pretty et al. & $\begin{array}{l}\text { The top } 100 \text { questions of } \\
\text { importance to the future of } \\
\text { global agriculture }\end{array}$ & $\begin{array}{l}\text { International Journal of } \\
\text { Agricultural Sustainability }\end{array}$ & 142 & 2010 & $\begin{array}{l}\text { [Pretty et al., } \\
\text { 2010] }\end{array}$ \\
\hline Ben Martin & $\begin{array}{l}\text { Foresight in Science and } \\
\text { Technology }\end{array}$ & $\begin{array}{l}\text { Technology Analysis \& } \\
\text { Strategic Management }\end{array}$ & 142 & 1995 & [Martin, 1995] \\
\hline Lena Neij & $\begin{array}{l}\text { Cost development of future } \\
\text { technologies for power } \\
\text { generation - A study based } \\
\text { on experience curves and } \\
\text { complementary bottom-up } \\
\text { assessments }\end{array}$ & Energy Policy & 132 & 2008 & {$[N e i j, 2008]$} \\
\hline $\begin{array}{l}\text { Sirkka Jarvenpaa } \\
\text { and Dorothy } \\
\text { Leidner }\end{array}$ & $\begin{array}{l}\text { An information company } \\
\text { in Mexico: Extending the } \\
\text { resource-based view of the } \\
\text { firm to a developing country } \\
\text { context }\end{array}$ & $\begin{array}{l}\text { Information Systems } \\
\text { Research }\end{array}$ & 103 & 1998 & $\begin{array}{l}\text { [Jarvenpaa, } \\
\text { Leidner, 2008] }\end{array}$ \\
\hline $\begin{array}{l}\text { Theodore Gordon } \\
\text { and Adam Pease }\end{array}$ & $\begin{array}{l}\text { RT Delphi: An efficient, } \\
\text { "round-less" almost real time } \\
\text { Delphi method }\end{array}$ & $\begin{array}{l}\text { Technological Forecasting } \\
\text { and Social Change }\end{array}$ & 100 & 2006 & $\begin{array}{c}\text { [Gordon, } \\
\text { Pease, 2006] }\end{array}$ \\
\hline $\begin{array}{l}\text { Murat Bengisu and } \\
\text { Ramzi Nekhili }\end{array}$ & $\begin{array}{l}\text { Forecasting emerging } \\
\text { technologies with the aid } \\
\text { of science and technology } \\
\text { databases }\end{array}$ & $\begin{array}{l}\text { Technological Forecasting } \\
\text { and Social Change }\end{array}$ & 99 & 2006 & $\begin{array}{c}{[\text { Bengisu, }} \\
\text { Nekhili, 2006] }\end{array}$ \\
\hline
\end{tabular}

\section{Figure 6. Ego Network of the Main Keyword "Decision Making"}

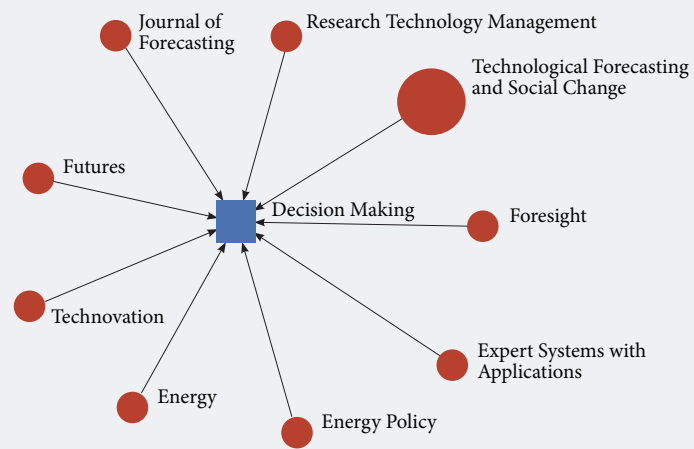

Source: compiled by the authors.

\section{Discussion}

Foresight literature is often classified as either descriptive or normative [Andersen et al., 2014]. Descriptive research is concerned with definitional consensus. Early efforts by researchers such as Irvine and Martin [Martin, 2010], Coates [Coates, 1985], and Miles [Miles, 2010] drove some degree of definitional consensus.

New methods and tools expanded the scope and methodologies. For example, Web 2.0 technologies created an opportunity for researchers to explore new methods such as online frameworks, social networks and mass collaboration approaches. This can be seen in a more recent description of foresight "as a social cognition process involving a complex set of methods and interactive process intended to assist policy in becoming more adaptive and forward-oriented in unpredictable environments" [Mendonça et al., 2012]. Web 3.0 readily incorporates machine learning techniques. 


\section{Figure 7. Sorted Ego Networks}

\section{a) "Technological Foresight"}

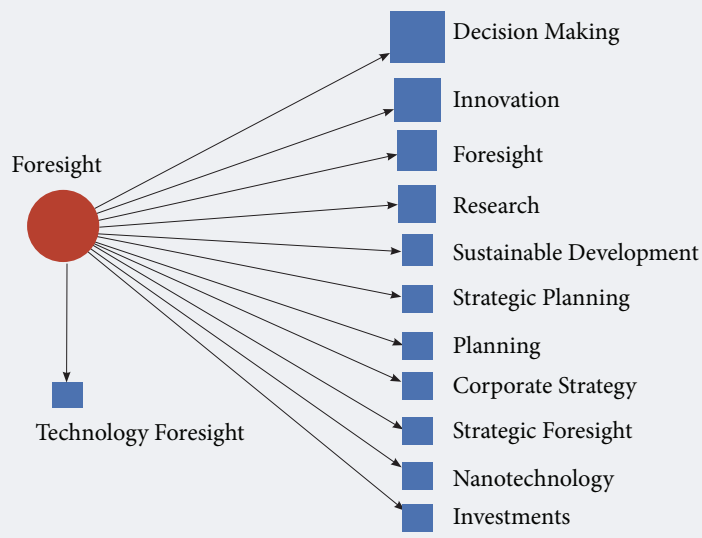

b) "Adaptive Foresight"

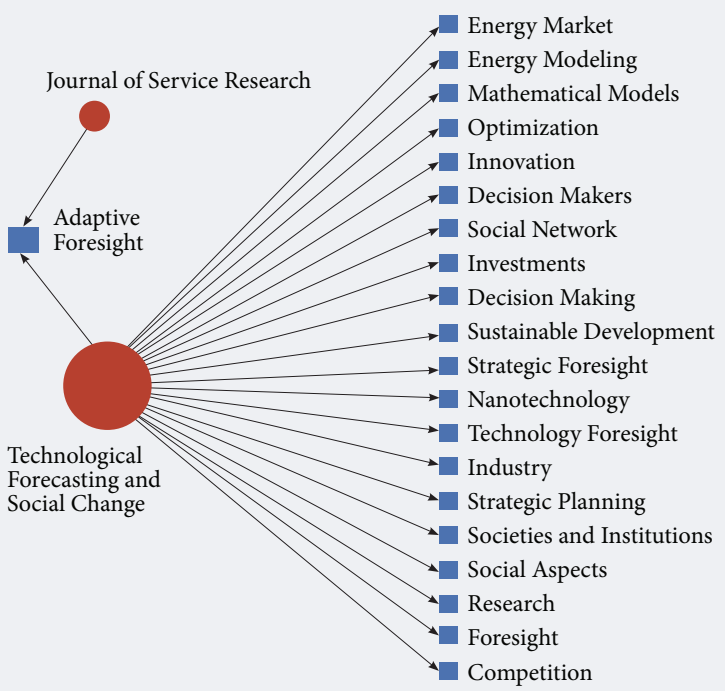

c) "Strategic Foresight"

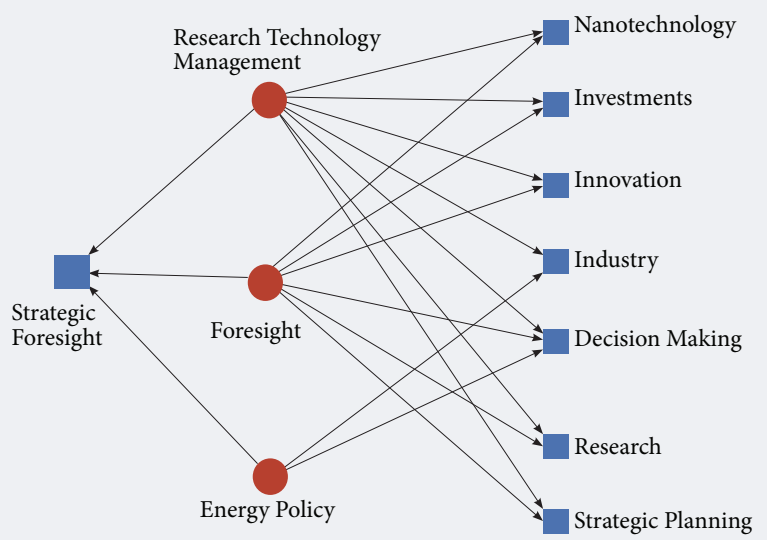

Source: compiled by the authors.
Grouping the concepts identified in Figure 3 shows that the majority of the research attempts to address the purpose, approach, and criteria. Figure 9 shows when the concepts are grouped into the concept of methods (social networks, modeling, optimization, Delphi, and scenarios) they are not as highly ranked as those grouped by purpose (decision making, innovation, research, competition, and sustainable development).

Policy making and public policy rank 44th and $45^{\text {th }}$, respectively. Decision making and innovation rank 1st and 2nd. Thus, a proper foresight study requires an innovative design approach and a structured process.

\section{Initiating a Foresight Study}

Coates states that "useful futures work can be performed on any scale, with any time dimension, and for any purpose" [Coates, 2010, p. 1431]. While the openness of the scope facilitates multi-disciplined use; it can lead to a lack of stakeholder consensus about the problem. This creates challenges. First, socio-technical and environmental problems are inherently complex because they are a national concern that involves cultural value and belief systems [Geels, 2004]. There is increasing uncertainty about a future that is approaching more rapidly than ever before. Thus, initiating a foresight study includes developing and documenting a clear purpose, articulating expected outputs, outcomes, impact, and structuring an approach.

Even when the mission is clear, stakeholders from different disciplines come with different perspectives. This is further complicated by an increased emphasis on collaborative research. While some researchers argue that the domain be restricted for a greater impact, others argue that foresight activities should span multiple domains [Calof, Smith, 2009]. In general, public entities involve governments and not-forprofit organizations, who seek knowledge expansion. Private and commercial entities, on the other hand, are becoming increasingly concerned about sustainable business. The lack of consensus in the foresight literature and related concepts is not caused by methodologies, but rather by scoping activities. Porter [Porter, 2005] argues the importance of understanding motivation. If explorative, foresight activities attempt to identify possible radical futures. However, if normative, the purpose is to identify a singular path towards one possible future. Thus, it is critical to clearly understand the purpose and target audience.

Foresight is important for national technology planning, commercial strategies, and industrial knowledge. Industrial groups, government, and academia conduct studies for knowledge expansion [Andersen et al., 2014; Gallouj et al., 2015]. Many countries engage in national foresight programs to assist them in cultural expansion or policy setting [Georghiou, Cassingena Harper, 2013; Keenan, Popper, 2008]. Most nations consider foresight activities essential for the health of their knowledge-based economies [Grupp, Linstone, 1999]. Companies, increasingly wary of disruption from changing market drivers [Rohrbeck, 2012], turn to foresight for options. Corporations use foresight activities for policy creation [Georghiou, Cassingena Harper, 2013], corporate sustainability [Costanzo, 2004; Rohrbeck, Gemünden, 2011; Destatte, 2010], or expansion [Kodama, 2004; Ju, Sohn, 2015]. For example, rapidly evolving nanotechnologies are of particular interest to the ICT and medical fields [Loveridge, Saritas, 2009]. Each organization has a unique interest in conducting foresight. Foresight studies 


\section{Figure 8. Ego Network for Foresight}

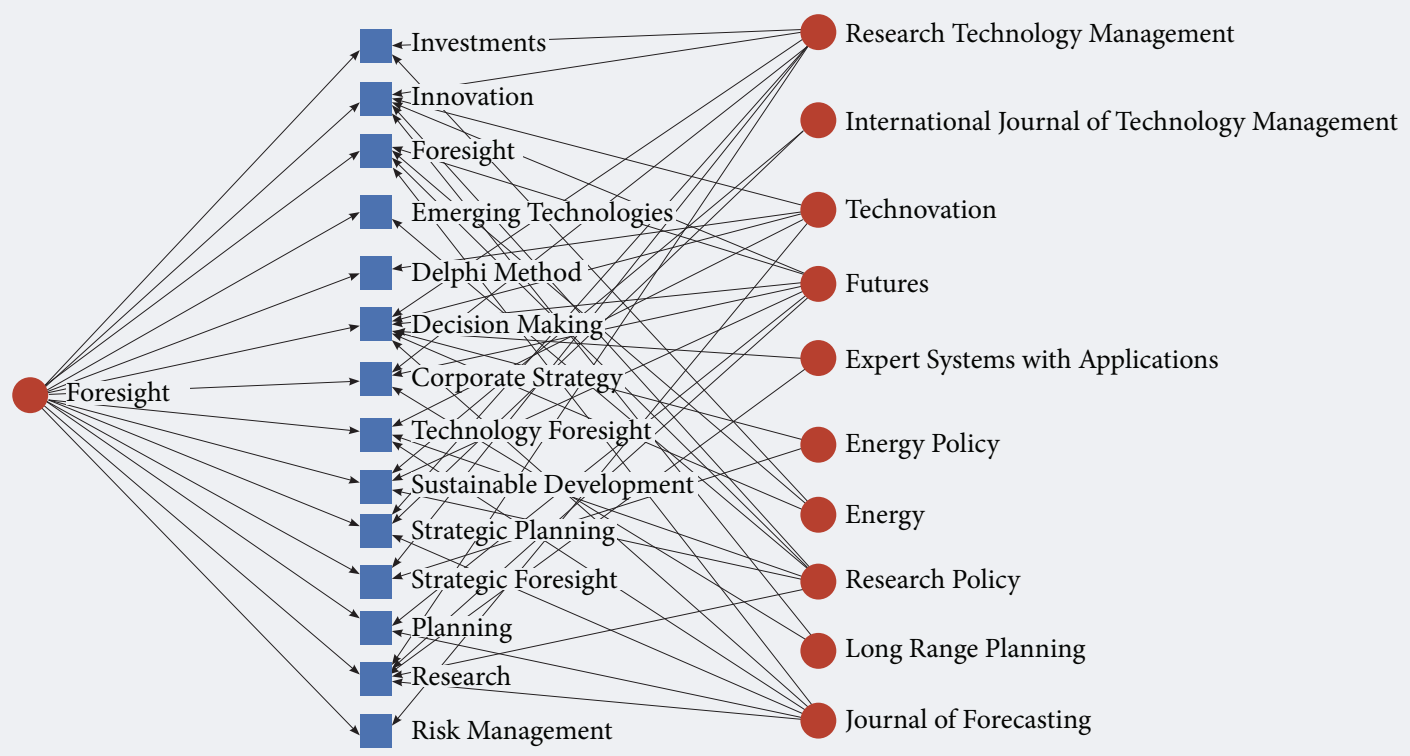

Source: compiled by the authors.

concerned with quality of life problems have a different focus than studies concerned with sustainable business [Wilburn, Wilburn, 2011].

Foresight is a process with inputs and outputs. In a properly designed foresight study, clear outputs that meet stakeholder expectations must be defined immediately. What are the outputs of a foresight study? One way to answer this question is to describe which group or process will be using the output from this activity as their input. If the purpose is to help identify changes to technology policy, the output could be in the form of a formal report or briefing. The outcome could be the drafting of a new bill and the impact could be its passage.

There are two main schools of thought about how to best approach technology foresight activities and prediction. The difference in these approaches seem to lie in the question of predicting a future by creating a strategic plan to make that future happen or by envisioning a direction that holds multiple possible futures and starting along a directional path open to adapting said vision of the future. Researchers affiliated with US institutions have related the terms "normative" to a desirable future perspective and "explorative" to a possible future [Roper et al., 2011]. For example, Major et al. [Major et al., 2001] argue

\section{Figure 9. Foresight Concepts}

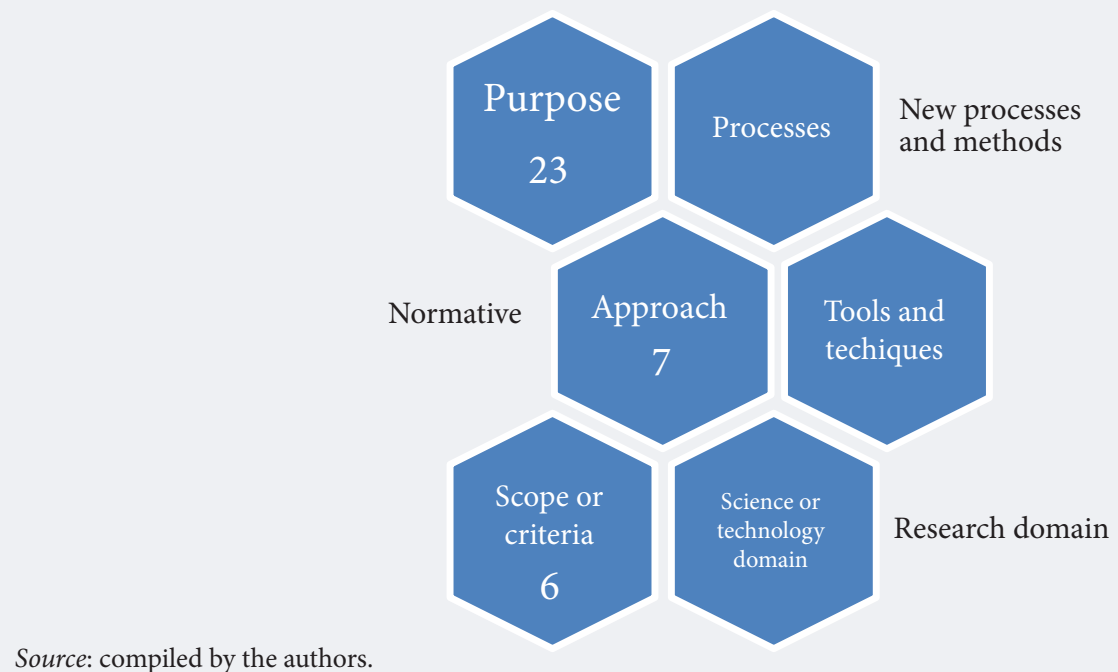


that foresight is aligned with strategic planning and management. In France, la prospective is discussed in terms of futuribles (possible futures) and futurables (desirable futures) [Godet, 2010]. Habegger argues for the benefit of distinguishing between possible and probable futures for improved policy development [Habegger, 2010]. Today, prospective has close ties with the concepts of strategic foresight [Godet, 2010]. Australia effectively used a strategic foresight approach to develop public policy [Leigh, 2003]. Public and private entities have been engaging more frequently in foresight activities that use both approaches [Habegger, 2010].

\section{The Adaptive vs. Strategic Approach}

The timeline and amount of environmental uncertainty must be established when selecting an approach [Coates, 2010]. Strategic foresight is more about identifying a preferable or desired future and creating a plan to achieve it. The adaptive (explorative) approach uses a modular design and a highly iterative foresight process [Lin et al., 2012] to transform the future as it evolves [Carlson, 2004]. The more dynamic the environment, the more an adaptive foresight process is needed to combat the greater amount of uncertainty in the continuously shifting environment [Andriopoulos, Gotsi, 2006]. In the late 1990s, McMaster introduced the concept of continuous integration into foresight activities while placing an emphasis on the "structure of the future" [McMaster, 1996, p. 149]. His argument that emerging technologies disrupted the scale of prediction rendered much of the past information irrelevant. This means that the structure of the future is more important than attempting to discern any linear nature or pattern detailing the shape of its path. Thus, he proposed that the structure of the future is a set of relationships within a complex adaptive system. Van der Meulen et al. discuss the fact that integrating learning through an interactive process provides more value and impact [van der Meulen et al., 2003].

Most of the adaptive foresight literature is focused on exploring new business opportunities in highly uncertain environments [Heger, Rohrbeck, 2012; Rohrbeck et al., 2015; Castorena et al., 2013]. This is not surprising because the number of "traditional industries undergoing radical change due to emerging technologies is unprecedented" [Groen, Walsh, 2013, p. 187]. In these dynamic environments, firms are finding it increasingly difficult to sustain their competitive advantages or even survive [Costanzo, 2004; Rohrbeck, Bade, 2012]. This complexity is driving higher levels of uncertainty, requiring decision makers to become more proactive in identifying different industry directions and possible futures. Thus, businesses require more relevant and timely [Robinson et al., 2013] intelligence to successfully respond to triggers [Rohrbeck, 2012] and apply strategic-foresight techniques for complex planning tasks such as exploring new business fields [Alkemade, Suurs, 2012; Heger, Rohrbeck, 2012; Rohrbeck, Kaab, 2013].

Statistical evidence shows a positive relationship between foresight and firm performance [Amsteus, 2011b]; however, quantitative studies comparing the different approaches are missing. Figure 10 shows how adaptive foresight differs from strategic foresight.

Some researchers [Rohrbeck, Oliver, 2013] believe that adaptive foresight may be the better method for emerging companies because the environment is dynamic and there is deep uncertainty [Hamarat et al., 2013]. What these companies need is a set of future visions that can be used in current decision making practices that are adaptable for future-oriented practices [Brummer et al., 2008]. Coates agrees that "there is a need for the development of easily comprehensible, timely, and cheap sources" of technological forecasting for small companies [Coates et al., 2001, p. 15].

The adaptive foresight approach could also be more appropriate for developing countries [Lin et al., 2012] because the expense, time, and other resource requirements are simply out of reach for developing countries that are strapped for cash with limited resources. However, one has to be careful in working with experts in different countries where there is great uncertainty [Knight, 1921] as experts will have differing motivations. On the other hand, Havas explored national foresight activities in a small country with a bias towards planning [Havas, 2003]. Others have also concluded that size, style, and culture matters [Keenan, Popper, 2008]. Cultural expectations and values are often associated with time. As more tools and methods are being introduced into the foresight process and societal problems become more complex, the adaptive approach is gaining popularity in both the public and private sectors.

In the adaptive school of thought, it is also critical to maintain an open foresight attitude to facilitate optimal cognitive learning [Bootz, 2010]. This is explained as being open to new or weak signals for the continued analysis of alternate possible paths. Actions will create new data for analysis over time as the firm marches towards a future unspecified point in a general direction. Within this context, learning is a key component because the managers conducting the foresight activities may also have an influence over the firm's actions. Bezold conducted a study to explore the effective use of scenarios and found parallel plausible paths through scenarios leading to the conclusion that a direction could be set for the path while work continues to clarify the vision [Bezold, 2010]. Thus, managers operating under these deeply uncertain environments are leaning towards the adaptive school of thought [Amsteus, 2011a; Kwakkel, Pruyt, 2013] for the purpose of sustainable business.

One must organize and structure the studies around a set of defined criteria. Typical criteria, in addition to the time horizon [Vecchiato, Roveda, 2010] and the environmental uncertainty, may include: resource requirements, the domain, and the risk tolerance associated with the output. Researchers know that 


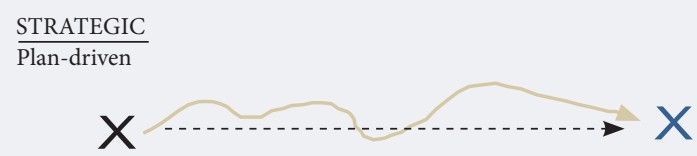

ADAPTIVE

Process-driven

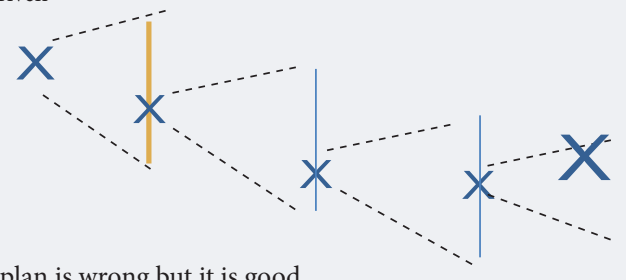

Deep uncertainty, short timeline. The plan is wrong but it is good

enough to point a direction. Modular design, iterative process.

Source: compiled by the authors.

no forecasting model captures the entire reality of the current environment and that the output never represents an accurate forecast. In foresight activities there is increased uncertainty as the future timeline is extended. As technology has rapidly advanced, researchers are becoming increasingly concerned about how to improve the foresight process and tailor it to different domains for different purposes [Heger, Boman, 2015].

\section{Executing a Foresight Study}

Selecting the right experts, designing data collection processes, and leveraging new methods and innovative analysis techniques are required for conducting a proper study. Many stakeholders and panels of experts are needed in order to balance perspectives. One French foresight exercise determined that 100 experts were not adequate and selected 50 more [Durand, 2003]. The selection of experts must take a balanced approach by carefully considering perspectives about technologies, industry, and culture.

The methods and tools used in foresight activities are eclectic, flexible, complex, and sophisticated [Coates, 2010]. Data collection methods and analysis techniques are rapidly evolving. Methods identified in Table 2 with high rankings include: bibliometrics, SNA, simulation and modeling, mathematical models and algorithms, optimization, Delphi surveys, business forecasting tools and techniques, and scenario analysis. Data collection methods and analysis techniques were grouped into quantitative, qualitative, or hybrid methods for further discussion.

Quantitative methods are numerically based and apply statistical analyses. Many of these tools are commonly found in forecasting activities. Some of these methods include: data-mining, bibliometrics and extrapolation.

Qualitative methods collect contextual data that can be analyzed to provide meaning to events and perceptions. Some of these tools and methods include: backcasting, brainstorming, panels, gaming, interviews, morphological boxes, and surveys. The hybrid methods are primarily focused on quantifying expert judgment. Some of these methods include cross-impact analysis, Delphi, multi-criteria analysis, scenario analysis, and roadmapping.

Delphi is popular as a data collection method because expert panels are "one of the most frequently used methods in foresight" [Daim et al., 2009, p. 32]. When used effectively, the Delphi method creates consensus and clarifies disagreements between experts. The experts remain anonymous in the process and the method is often combined with other methods such as other expert panels, mapping, scenarios, etc. Several researchers provided good discussions about characteristics pertaining to selecting and working with experts [Loveridge, Saritas, 2009; Tichy, 2004].

Scanning and scouting for strategic intelligence are other methods to collect data. This area is evolving in the literature because monitoring for information can be difficult and some of the signals can be weak [Ilmola, Kuusi, 2006], disjointed, or convoluted with inconsistent terminology. Open attitudes are critical in order to avoid introducing bias.

Delphi surveys, scenario analysis, and roadmapping are used to promote creativity based upon the assumptions about the future, the collection of knowledge and experience from experts, and the interaction of experts to find a congruent collective consensus [Cachia et al., 2007]. While foresight 
activities may use some purely qualitative methods that are narrative based, a proper study requires multiple tools and methods [Smith, Saritas, 2011].

Different methods have varying strengths and weaknesses. For example, if the objective is to identify low probability-high impact events, also known as a black swan, forecasting methods could be used based upon what-if scenarios. This also illustrates how the qualitative method of scenario planning is mixed with heavily quantitative forecasting methods. On the other hand, if an organization is concerned about sustainable development or emerging industries, combing the patent databases using bibliometrics could detect patterns in $\mathrm{R} \& \mathrm{D}$ or shifting resources.

Coates [Coates, 2010] identifies and describes the use of over seventeen different methods in the description of a properly conducted futures study. Popper [Popper, 2008], conducted an extensive research study to investigate how methods are selected and applied by examining 886 different foresight studies from around the globe. The resulting diamond-shaped framework classified thirty-three of the most important methods in terms of interaction, creativity, evidence, and expertise.

A foresight study is a project with a beginning, an end, specific purpose and outcomes requiring multiple processes and activities. A framework is useful to manage complexity. Figure 11 adapts Voros's threephase framework [Voros, 2003] to map methods that help selecting methods to conduct a three-phase study: initiating, executing, and communicating the results. Five dimensions were used to map each method: purpose, time, domain, uncertainty level, and resource availability.

The systematic use of a framework is important. Consider how stakeholders involved in both foresight planning activities and policy development can influence actions [Bootz, 2010]. Without an open attitude about knowledge expansion, bias towards a particular path may eliminate other worthy avenues prematurely. Including objectives for both knowledge creation and sustainable business helps one find a balance between knowledge expansion for the sake of knowledge expansion or knowledge expansion for the sake of sustainable business.

Porter discusses how during a normative study, the preferable future is characterized by ethics, values, and virtues [Porter et al., 2004]. Glenn and Coates [Glenn, Coates, 2009] describe normative forecasts as consisting of two essential parts: (1) the statement of a goal or set of goals to be accomplished in a specific time period and (2) a detailed analysis of how to reach the goal or goals. Porter clarifies that normative techniques are more goal-oriented, working towards a firm's mission. Thus, normative techniques tend to move backwards in attempt to control actions aimed at realizing the vision. The construction of normative narratives can create scenarios for out-of-the-box thinking that helps to break conventional thinking patterns [Andreescu et al., 2013]. Examples of purely normative methods are: analytical hierarchy process (HDM), backcasting, multi-criteria decision analyses, participatory techniques, requirements analysis, science fiction analysis, and stakeholder analysis.

Explorative techniques investigate future possibilities depicted by scenarios of shifting forces; using historical chronological data that spans from the past into the future. An exploratory forecasting exercise is undertaken for the purpose of examining where the future may go without any consideration of whether people or society want it to go there or not. Examples of purely exploratory methods are: agent modeling, analogies, bibliometrics, causal models, checklists for impact identification, complex adaptive system modeling, correlation analysis, cost-benefit analysis, cross-impact analysis, demographics, diffusion modeling, economic base modeling, innovation system modeling, institutional analysis, long wave analysis, monitoring, organizational analysis, precursor analysis, sustainability analysis, systems simulation, technological substitution, technology assessment, and trend extrapolation. Some methods are a combination of both normative and exploratory forecasting. These methods include: action analysis, brainstorming, creativity workshops, decision analysis, Delphi, focus groups, interviews, multiple perspectives assessment, risk analysis, roadmapping, scenarios, scenario-simulation, social impact assessment, and TRIZ (theory of the resolution of invention-related tasks).

Time is a key dimension in any foresight activity. Is the possible future to be specified for the near future, next future, or far future? For example, Alsan and Oner's research [Alsan, Oner, 2003] defines the time periods as follows: at the normative level - eight to thirty years, the strategic level - four to seven years, and the operative level - one to three years. The time dimension began to be more directly linked to the different approaches and impact levels. For example, Johnston [Johnston, 2012] described the impact in terms of instrumental, conceptual, and capacity building. Other time relationships are discussed in terms of output objectives such as knowledge building and business sustainability. Other researchers use only two: future and past where the time in the past is extrapolated into the future using present conditions and criteria. Recently, researchers have been looking to technology foresight rather than forecasting for even shorter time spans for environments where deep uncertainty prevails [Hamarat et al., 2013]. Typically for the same environment, the farther into the future, the more uncertain is the prediction of what the environment will be. However, it is known that different environments carry different unknowns with different uncertainties [Keenan, Popper, 2008]. Thus, the domain is another dimension to consider.

High or deep levels of uncertainty can impact the time horizon [Hamarat et al., 2013; Salo, Gustafsson, 2003] and method selections. For example, Andreescu et al. [Andreescu et al., 2013] illustrated how the method of scenario analysis was selected for a systems foresight exercise because the domain for the 


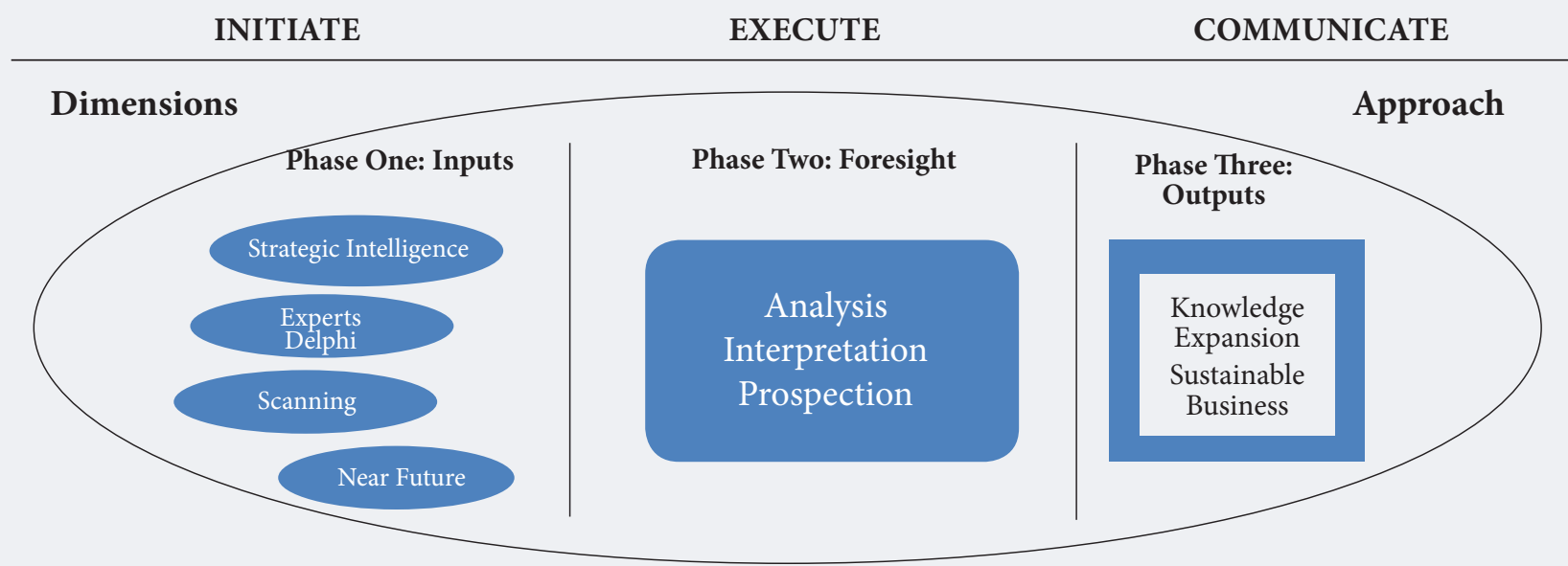

\section{Scanning \\ Bibliometrics \\ Crowd Sourcing \\ Scouting \\ Expert Networks \\ Literature Review \\ Trends/Drivers/Indicators \\ System Mapping \\ Panel Workshops \\ Checklists for Impact}

Gaming, Scenario Planning
Wild Card / Weak Signals
Network Analysis
Agent-based Modeling
Dynamic Simulations
Panel Workshops
SWOT Analysis
Multi-Criteria Analysis
Scenario Comparisons
Causal Models
Adaptive Modeling
Trend Extrapolation
Delphi
Scoring/Voting
Benefit/Cost/Risk Analysis
Backcasting
Roadmapping
Emerging Pathways
Correlation Analysis
Long Wave Analysis

Relevance Trees

Roadmaps

Strategic Plans

Logic Charts

Priority Lists

Impact Assessments

Primary Method Key: Black $=$ Strategic $($ Normative $)$, Italic $=$ Adaptive $($ Explorative $)$, Bold $=$ Both .

Source: compiled by the authors. based on [Voros, 2003].

future university education environment in Romania was highly uncertain and little historical data was available [Andreescu et al., 2013]. Others have selected patent data mining over Delphi because Delphi uses expert quantification and is time sensitive [Hung et al., 2013]. Thus, time and uncertainty is highly dependent upon the domain.

Some foresight methods are known to require significant monetary resources and time such as Delphi, scenarios, participatory methods, and technology roadmapping. Thus, these high resource methods, while effective and popular, may simply not be practical due to either monetary or time restrictions. Methods most commonly referenced for small and emerging companies include: backcasting, bibliometrics, diffusion modeling, longwave analysis, monitoring technological substitution, trend extrapolation, and scenario analysis. Companies that use these less resource-intensive methods could also include difficult industries currently experiencing a great amount of uncertainty such as bio-tech, health [Masum et al., 2010], and universities [Andreescu et al., 2013]. Companies operating in this domain require adaptive and robust foresight activities [Kwakkel, Pruyt, 2013; Hamarat et al., 2013].

Ruff conducted an extensive research study on how small and medium enterprises (SMEs) conduct strategic foresight [Ruff, 2006]. What he found was they are operating in a vastly different resource 
environment, lacking strategic planning organizations, research and technology divisions, and other support functions. Thus, many of the technology foresight methods are simply not practical for them. He also found their time span was shorter, typically from 1-10 years and the duration of the foresight activity lasted between 3-6 months. Therefore, the major methods for this group would be data-mining and bibliometric techniques, expert interviews, technology monitoring/scanning, quantitative models, and trend research. While several researchers noted a gap in this research, Ruff's study was the only study found in the content analysis of literature that focused on SMEs.

One reason may be that the process requires flexibility in the selection of input criteria and methods to achieve expected outcomes. Input criteria such as market drivers or technical parameters may be highly uncertain. Or, enterprises may be faced with new market drivers and technical constraints where time series data for the desired criteria may simply not be available. In these cases, researchers have found the tools and methods to be lacking [Barker, Smith, 1995] and that they require additional research [Linstone, 2011]. Some progress has been made with new data mining techniques [Huang et al., 2014] that create smarter ways to capture large amounts of data. These tools are useful to examine and understand the dynamics of the emerging field. Another problem is that the data may be located in pockets and change rapidly, which makes it more difficult to apply these data mining techniques.

\section{Communicate Results}

The dissemination of the results to the appropriate audience is important. The foresight process uses multiple methods requiring increasing amounts of communication. One strength in technology roadmapping is that a map is produced as part of the activity. This output can be used as a blueprint facilitating communication that facilitates making a new technology a reality. Whether the outputs are in the form of a written report, document, presentation, or roadmap it is critical that the results are communicated and disseminated.

\section{Conclusions and Directions for Future Research}

Rapidly increasing technology, tools, and methods require that facilitators of foresight activities use a framework to initiate, execute, and conclude each study. Methods used to conduct a proper foresight study in the past may no longer be relevant for the problem under consideration today.

The study shows marked improvement in and the usage of bibliometric tools used for data and text mining and patent analysis. Porter's work has significantly contributed to this trend [Porter, 2005]. "Computation and simulation are becoming indispensable for managing the complexities of future variables and the enormous range of drivers, factors, and implications" [Smith, Saritas, 2011]. Better tools can be used concurrently with one another in order to yield better results. Communication and the importance and breadth of stakeholders continues to be an important discussion point.

The other trend is the move towards iterative processes and sustainable business. Literature increasingly emphasizes the importance of measuring the impact of the study. This can only be done by continuously testing assumptions and predictions against the baseline study. Many researchers have documented a gap in foresight research between theory and practice [Georghiou, Cassingena Harper, 2013; Keenan, Popper, 2008; Bootz, 2010]. One reason may be that the activity may provide a competitive edge, so companies are not willing to share their information. Taken a step further, organizations may be viewing foresight activities as a core competency that provides a competitive advantage. Eriksson and Weber [Eriksson, Weber, 2008] discuss this in more detail and others have begun to fill the gap with case studies [Andersen, Rasmussen, 2014] and examinations of weak signals [Battistella, de Toni, 2011]. The bottom line here is that better evaluation tools are necessary [van der Meulen et al., 2003] before foresight activities can become a part of routine decision making [Glenn, 2013]. More research is needed to understand which organizational structure [Cagnin et al., 2013] and measurement system [Schwartz, 2008] are needed because currently the results are often vague and difficult to integrate into corporation [Durand, 2008]. Rohrbeck and Schwarz call for more research to understand the value generated by foresight methods for the corporation and which practices will best deliver that value [Heger, Rohrbeck, 2012; Rohrbeck, Oliver, 2013; Schwartz, 2008].

Other researchers noted gaps between other fields [Könnölä et al., 2007], suggesting foresight draw from other academic disciplines such as strategic management [Amsteus, 2011a], innovation systems [Alkemade, Suurs, 2012; Andersen et al., 2014; Smith, Saritas, 2011], or cultural differences [Andersen, Rasmussen, 2014] and style [Keenan, Popper, 2008]. Strategic decision making under conditions of uncertainty is a key concern for technology managers. Despite the importance for sustainable business, the research connecting foresight theory with strategic decision making is sparse [Vecchiato, 2012]. Saritas sheds some light on the fragmentation by explaining that foresight is highly context-dependent [ElenaPérez et al., 2011]. Others consider the connections with other foresight activities critical and emphasize the importance of networking with 'distributive intelligence tools' [de Lattre-Gasquet et al., 2003].

The quantitative analyses provided above can be further improved by trying to normalize the results by using the impact factors of the journals. This would be an interesting test of the relevance of our results. 


\section{References}

Alkemade F., Suurs R.A.A. (2012) Patterns of expectations for emerging sustainable technologies. Technological Forecasting and Social Change, vol. 79, no. 3, pp. 448-456.

Alsan A., Oner M.A. (2003) An integrated view of foresight: Integrated foresight management model. Foresight, vol. 5, no 2, pp. 33-45.

Amsteus M. (2011a) Managerial foresight: Measurement scale and estimation. Foresight, vol. 13, no 1, pp. 58-76.

Amsteus M. (2011b) Managers' foresight matters. Foresight, vol. 13, no 2, pp. 64-78.

Andersen P.D., Rasmussen L.B. (2014) The impact of national traditions and cultures on national foresight processes. Futures, vol. 59, pp. 5-17.

Andersen P.D., Andersen A.D., Jensen P.A., Rasmussen B. (2014) Sectoral innovation system foresight in practice: Nordic facilities management foresight. Futures, vol. 61, pp. 33-44.

Andreescu L., Gheorghiu R., Zulean M., Curaj A. (2013) Understanding normative foresight outcomes: Scenario development and the 'veil of ignorance' effect. Technological Forecasting and Social Change, vol. 80, no 4, pp. 711-722.

Andriopoulos C., Gotsi M. (2006) Probing the future: Mobilising foresight in multiple-product innovation firms. Futures, vol. 38, no 1, pp. 50-66.

Barker D., Smith D.J.H. (1995) Technology foresight using roadmaps. Long Range Planning, vol. 28, no 2, pp. 21-28.

Battistella C., De Toni A.F. (2011) A methodology of technological foresight: A proposal and field study. Technological Forecasting and Social Change, vol. 78, no 6, pp. 1029-1048.

Bengisu M., Nekhili R. (2006) Forecasting emerging technologies with the aid of science and technology databases. Technological Forecasting and Social Change, vol. 73, no 7, pp. 835-844.

Bezold C. (2010) Lessons from using scenarios for strategic foresight. Technological Forecasting and Social Change, vol. 77, no 9, pp. 1513-1518.

Blind K., Cuhls K., Grupp H. (1999) Current Foresight Activities. Technological Forecasting and Social Change, vol. 60 , no. 1, pp. 15-35.

Bootz J.-P. (2010) Strategic foresight and organizational learning: A survey and critical analysis. Technological Forecasting and Social Change, vol. 77, no 9, pp. 1588-1594.

Boretos G.P. (2011) IS model: A general model of forecasting and its applications in science and the economy. Technological Forecasting and Social Change, vol. 78, no 6, pp. 1016-1028.

Brandes F. (2009) The UK technology foresight programme: An assessment of expert estimates. Technological Forecasting and Social Change, vol. 76, no 7, pp. 869-879.

Brummer V., Könnölä T., Salo A. (2008) Foresight within ERA-NETs: Experiences from the preparation of an international research program. Technological Forecasting and Social Change, vol. 75, no 4, pp. 483-495.

Cachia R., Compañó R., Da Costa O. (2007) Grasping the potential of online social networks for foresight. Technological Forecasting and Social Change, vol. 74, no 8, pp. 1179-1203.

Cagnin C., Havas A., Saritas O. (2013) Future-oriented technology analysis: Its potential to address disruptive transformations. Technological Forecasting and Social Change, vol. 80, no 3, pp. 379-385.

Calof J., Smith J. (2009) The integrative domain of foresight and competitive intelligence and its impact on R\&D management. R\&D Management, vol. 40, no 1, pp. 31-39.

Calof J., Smith J. (2012) Foresight impacts from around the world: A special issue. Foresight, vol. 14, no 1, pp. 82-97.

Carlson L. (2004) Using technology foresight to create business value. Research-Technology Management, vol. 47, no 5, pp. 50-60.

Castorena D.G., Rivera G.R., González A.V. (2013) Technological foresight model for the identification of business opportunities (TEFMIBO). Foresight, vol. 15, no 6, pp. 492-516.

Chavez V. (2013) Creative enterprise as a solution vector for twenty first century problems. Technological Forecasting and Social Change, vol. 80, no 2, pp. 191-193.

Chen J.K.C., Kien Pham V. (2014) A study on knowledge flows of dye-sensitized solar cells' patent. Foresight, vol. 16, no 3, pp. 229-249.

Chien S.-H., Weng C.S. (2012) The network effect on technological innovation - By the analysis of affiliation network. Foresight, vol. 14, no 2, pp. 168-178.

Choi C., Park Y. (2009) Monitoring the organic structure of technology based on the patent development paths. Technological Forecasting and Social Change, vol. 76, no 6, pp. 754-768.

Coates J., Durance P., Godet M. (2010) Strategic Foresight Issue: Introduction. Technological Forecasting and Social Change, vol. 77, no 9, pp. 1423-1425.

Coates J.F. (1985) Foresight in Federal Government Policy Making. Futures Research Quarterly, vol. 1, pp. $29-53$.

Coates J.F. (2010) The future of foresight - A US perspective. Technological Forecasting and Social Change, vol. 77, no 9, pp. 1428-1437.

Coates V., Farooque M., Klavans R., Lapid K., Linstone H.A., Pistorius C., Porter A.L. (2001) On the future of technological forecasting. Technological Forecasting and Social Change, vol. 67, no 1, pp. 1-17.

Costanzo L.A. (2004) Strategic foresight in a high-speed environment. Futures, vol. 36, no 2, pp. 219-235.

Cuhls K. (2003) From forecasting to foresight processes-new participative foresight activities in Germany. Journal of Forecasting, vol. 22, no 2-3, pp. 93-111.

Daim T., Basoglu N., Dursun O., Saritas O., Gerdsri P. (2009) A comprehensive review of Turkish technology foresight project. Foresight, vol. 11, no 1, pp. 21-42. 
de Jordy R., Halgin D. (2008) Introduction to Ego Network Analysis, Briarcliff Manor, NY: Academy of Management. de Lattre-Gasquet M., Petithuguenin P., Sainte-Beuve J. (2003) Foresight in a research institution: A critical review of two exercises. Journal of Forecasting, vol. 22, no 2-3, pp. 203-217.

Destatte P. (2010) Foresight: A major tool in tackling sustainable development. Technological Forecasting and Social Change, vol. 77, no 9, pp. 1575-1587.

DTI (2000) The Age Shift: Priorities for Action. Ageing Population Panel. Foresight: Making the Future Work for You, London: Department of Trade and Industry.

Durand T. (2003) Twelve lessons from 'Key Technologies 2005': The French technology foresight exercise. Journal of Forecasting, vol. 22, no 2-3, pp. 161-177.

Durand T. (2008) Scenarios as knowledge transformed into strategic representations: The use of foresight studies to help shape and implement strategy. Management \& Avenir, vol. 3, no 17, pp. 279-297. DOI 10.3917/mav.017.0279.

Ecken P., Gnatzy T., von der Gracht H.A. (2011) Desirability bias in foresight: Consequences for decision quality based on Delphi results. Technological Forecasting and Social Change, vol. 78, no 9, pp. 1654-1670.

Elena-Pérez S., Saritas O., Pook K., Warden C. (2011) Ready for the future? Universities' capabilities to strategically manage their intellectual capital. Foresight, vol. 13, no 2, pp. 31-48.

Eriksson E.A., Weber K.M. (2008) Adaptive Foresight: Navigating the complex landscape of policy strategies. Technological Forecasting and Social Change, vol. 75, no 4, pp. 462-482.

European Commission (2009) Mapping Foresight: Revealing how Europe and other world regions navigate into the future (Report EUR 24041 EN, November), Brussels: European Commission.

Gallouj F., Weber K.M., Stare M., Rubalcaba L. (2015) The futures of the service economy in Europe: A foresight analysis. Technological Forecasting and Social Change, vol. 94, pp. 80-96.

Geels F.W. (2004) From sectoral systems of innovation to socio-technical systems. Research Policy, vol. 33, no 6-7, pp. 897-920.

Georghiou L., Cassingena Harper J. (2013) Rising to the challenges - Reflections on Future-oriented Technology Analysis. Technological Forecasting and Social Change, vol. 80, no 3, pp. 467-470.

Georghiou L., Edler J., Uyarra E., Yeow J. (2014) Policy instruments for public procurement of innovation: Choice, design and assessment. Technological Forecasting and Social Change, vol. 86, pp. 1-12.

Glenn J., Coates J. (2009) Normative Forecasting. Futures Research Methodology - Version 3.0 (CD-ROM).

Glenn J.C. (2013) Collective intelligence systems and an application by The Millennium Project for the Egyptian Academy of Scientific Research and Technology. Technological Forecasting and Social Change, vol. 97, pp. 7-14.

Godet M. (2010) Future memories. Technological Forecasting and Social Change, vol. 77, no 9, pp. 1457-1463.

Godin B. (1998) Measuring knowledge flows between countries: The use of scientific meeting data. Scientometrics, vol. 42, no 3, pp. 313-323.

Gordon T., Pease A. (2006) RT Delphi: An efficient, "round-less" almost real time Delphi method. Technological Forecasting and Social Change, vol. 73, no 4, pp. 321-333. Available at: https://doi.org/10.1016/j.techfore.2005.09.005, accessed 19.03.2017.

Groen A.J., Walsh S.T. (2013) Introduction to the field of creative enterprise. Technological Forecasting and Social Change, vol. 80, no 2, pp. 187-190.

Grupp H., Linstone H.A. (1999) Around the Globe Resurrection and New Paradigms. Foresight, vol. 94, pp. 85-94.

Habegger B. (2010) Strategic foresight in public policy: Reviewing the experiences of the UK, Singapore, and the Netherlands. Futures, vol. 42, no 1, pp. 49-58.

Hamarat C., Kwakkel J.H., Pruyt E. (2013) Adaptive Robust Design under deep uncertainty. Technological Forecasting and Social Change, vol. 80, no 3, pp. 408-418.

Havas A. (2003) Evolving foresight in a small transition economy. Journal of Forecasting, vol. 22, no 2-3, pp. $179-201$.

Heger T., Boman M. (2015) Networked foresight - The case of EIT ICT Labs. Technological Forecasting and Social Change, vol. 101, pp. 147-164.

Heger T., Rohrbeck R. (2012) Strategic foresight for collaborative exploration of new business fields. Technological Forecasting and Social Change, vol. 79, no 5, pp. 819-831.

Horton A. (1999) Forefront: A simple guide to sucessful foresight. Foresight, vol. 1, no 1, pp. 5-9.

Huang L., Zhang Y., Guo Y., Zhu D., Porter A.L. (2014) Four dimensional Science and Technology planning: A new approach based on bibliometrics and technology roadmapping. Technological Forecasting and Social Change, vol. 81, no 1, pp. 39-48.

Hung C.-Y., Lee W.-Y., Wang D.-S. (2013) Strategic foresight using a modified Delphi with end-user participation: A case study of the iPad's impact on Taiwan's PC ecosystem. Technological Forecasting and Social Change, vol. 80, no 3, pp. 485-497.

Ilmola L., Kuusi O. (2006) Filters of weak signals hinder foresight: Monitoring weak signals efficiently in corporate decision-making. Futures, vol. 38, no 8, pp. 908-924.

Irvine J., Martin B. (1984) Foresight in Science: Picking the Winners, Aldershot: Edward Elgar.

Jarvenpaa S.L., Leidner D.E. (1998) An information company in Mexico: Extending the resource-based view of the firm to a developing country context. Information Systems Research, vol. 9, no 4, pp. 342-361.

Johnston R. (2012) Developing the capacity to assess the impact of foresight. Foresight, vol. 14, no 1, pp. 56-68.

Ju Y., Sohn S.Y. (2015) Patent-based QFD framework development for identification of emerging technologies and related business models: A case of robot technology in Korea. Technological Forecasting and Social Change, vol. 94, pp. 44-64.

Keenan M., Popper R. (2008) Comparing foresight 'style' in six world regions. Foresight, vol. 10, no 6, pp. 16-38.

Knight F. (1921) Risk, Uncertainty and Profit, Boston; New York: Houghton Mifflin Company; The Riverside Press Cambridge. 
Kodama F. (2004) Measuring emerging categories of innovation: Modularity and business model. Technological Forecasting and Social Change, vol. 71, no 6, pp. 623-633.

Könnölä T., Brummer V., Salo A. (2007) Diversity in foresight: Insights from the fostering of innovation ideas. Technological Forecasting and Social Change, vol. 74, no 5, pp. 608-626.

Kwakkel J.H., Pruyt E. (2013) Exploratory Modeling and Analysis, an approach for model-based foresight under deep uncertainty. Technological Forecasting and Social Change, vol. 80, no 3, pp. 419-431.

Lee S., Yoon B., Park Y. (2009) An approach to discovering new technology opportunities: Keyword-based patent map approach. Technovation, vol. 29, no 6-7, pp. 481-497.

Leigh A. (2003) Thinking Ahead: Strategic Foresight and Government. Australian Journal of Public Administration, vol. 62 , no 2, pp. 3-10.

Lin H.-C., Luarn P., Maa R.-H., Chen C.-W. (2012) Adaptive foresight modular design and dynamic adjustment mechanism: Framework and Taiwan case study. Technological Forecasting and Social Change, vol. 79, no 9, pp. $1583-1591$.

Linstone H.A. (2011) Three eras of technology foresight. Technovation, vol. 31, no 2-3, pp. 69-76.

Loveridge D., Saritas O. (2009) Reducing the democratic deficit in institutional foresight programmes: A case for critical systems thinking in nanotechnology. Technological Forecasting and Social Change, vol. 76, no 9, pp. 1208-1221.

Major E., Asch D., Cordey-Hayes M. (2001) Foresight as a core competence. Futures, vol. 33, no 2, pp. 91-107.

Martin B. (1995) Foresight in Science and Technology. Technology Analysis \& Strategic Management, vol. 7, no 2, pp. 139-168. DOI: 10.1080/09537329508524202.

Martin B., Johnston R. (1999) Technology Foresight for Wiring Up the National Innovation System Experiences in Britain, Australia, and New Zealand. Technological Forecasting and Social Change, vol. 60, pp. 37-54.

Martin B.R. (2010) The origins of the concept of 'foresight' in science and technology: An insider's perspective. Technological Forecasting and Social Change, vol. 77, no 9, pp. 1438-1447.

Masum H., Ranck J., Singer P.A. (2010) Five promising methods for health foresight. Foresight, vol. 12, no 1, pp. 54-66.

Maynard A.D. (2007) Nanotechnology: The next big thing, or much ado about nothing? The Annals of Occupational Hygiene, vol. 51, no 1, pp. 1-12.

McDowall W., Eames M. (2006) Forecasts, scenarios, visions, backcasts and roadmaps to the hydrogen economy: A review of the hydrogen futures literature. Energy Policy, vol. 34, pp. 1236-1250.

McMaster M. (1996) Foresight: Exploring the Structure of the Future. Long Range Planning, vol. 29, no 2, pp. 149-155.

Mendonça S., Cardoso G., Caraça J. (2012) The strategic strength of weak signal analysis. Futures, vol. 44, no 3 , pp. $218-228$.

Miles I. (2010) The development of technology foresight: A review. Technological Forecasting and Social Change, vol. 77, no 9, pp. 1448-1456.

Neij L. (2008) Cost development of future technologies for power generation - A study based on experience curves and complementary bottom-up assessments. Energy Policy, vol. 36, no 6, pp. 2200-2211.

Phaal R. (2002) Foresight Vehicle Technology Roadmap. Technology and Research Directions for Future Road Vehicles, London: Department of Trade and Industry.

Phaal R., Farrukh C.J.P., Probert D.R. (2004) Technology roadmapping - A planning framework for evolution and revolution. Technological Forecasting \& Social Change, vol. 71, pp. 5-26.

Popper R. (2008) How are foresight methods selected? Foresight, vol. 10, no 6, pp. 62-89.

Porter A.L. (2005) QTIP: Quick technology intelligence processes. Technological Forecasting and Social Change, vol. 72, no 9, pp. 1070-1081.

Porter A.L., Ashton B., Clar G., Coates J.F., Cuhls K., Cunningham S.W., Ducatel K., van der Duin P., Georghiou L., Gordon T., Linstone H., Marchau V., Massari G., Miles I., Mogee M., Salo A., Scapolo F., Smits R., Thissen W. (2004) Technology futures analysis: Toward integration of the field and new methods. Technological Forecasting and Social Change, vol. 71, no 3, pp. 287-303.

Pretty J., Sutherland W.J., Ashby J., Auburn J., Baulcombe D., Bell M., Bentley J., Bickersteth S., Brown K., Burke J., Campbell H., Chen K., Crowley E., Crute I., Dobbelaere D., Edwards-Jones G., Funes-Monzote F., Godfray C.H.J., Griffon M., Gypmantisiri P., Haddad L., Halavatau S., Herren H., Holderness M., Izac A.-M., Jones M., Koohafkan P., Lal R., Lang T., McNeely J., Mueller A., Nisbett N., Noble A., Pingali P., Pinto Y., Rabbinge R., Ravindranath N.H., Rola A., Roling N., Sage C., Settle W., Sha J.M., Shiming L., Simons T., Smith P., Strzepeck K., Swaine H., Terry E., Tomich T.P., Toulmin C., Trigo E., Twomlow S., Vis J.K., Wilson J., Pilgrim S. (2010) The top 100 questions of importance to the future of global agriculture. International Journal of Agricultural Sustainability, vol. 8, no 4, pp. 219-236. DOI: 10.3763/ijas.2010.0534.

Pretty J., Toulmin C., Williams S. (2011) Sustainable intensification in African agriculture. International Journal of Agricultural Sustainability, vol. 9, no 1, pp. 5-24.

Robinson D.K.R., Huang L., Guo Y., Porter A.L. (2013) Forecasting Innovation Pathways (FIP) for new and emerging science and technologies. Technological Forecasting and Social Change, vol. 80, no 2, pp. 267-285.

Rohrbeck R. (2010) Harnessing a network of experts for competitive advantage: Technology scouting in the ICT industry. ReD Management, vol. 40, no 2, pp. 169-180.

Rohrbeck R. (2012) Exploring value creation from corporate-foresight activities. Futures, vol. 44, no 5, pp. $440-452$.

Rohrbeck R., Bade M. (2012) Environmental scanning, futures research, strategic foresight and organizational future orientation: A review, integration, and future research directions. Paper presented at the XXIII ISPIM Annual Conference, Barcelona, Spain.

Rohrbeck R., Gemünden H. G. (2011) Corporate foresight: Its three roles in enhancing the innovation capacity of a firm. Technological Forecasting and Social Change, vol. 78, no 2, pp. 231-243. 
Rohrbeck R., Kaab S. (2013) Collaborative business modelling for systemic and sustainability innovations. International Journal of Technology Management, vol. 63, no 1/2, pp. 4-23.

Rohrbeck R., Oliver J. (2013) The value contribution of strategic foresight: Insights from an empirical study of large European companies. Technological Forecasting and Social Change, vol. 80, no 8, pp. 1593-1606.

Rohrbeck R., Thom N., Arnold H. (2015) IT tools for foresight: The integrated insight and response system of Deutsche Telekom Innovation Laboratories. Technological Forecasting and Social Change, vol. 97, pp. 115-126.

Roper A.T., Cunningham S.W., Porter A.L., Mason T.W., Rossini F.A., Banks J. (2011) Forecasting and Management of Technology ( $2^{\text {nd }}$ ed.), Hoboken, NJ: Wiley.

Ruff F. (2006) Corporate foresight: Integrating the future business environment into innovation and strategy. International Journal of Technology Management, vol. 34, no 3-4, p. 278-295.

Salo A., Gustafsson T. (2003) Multicriteria Methods for Technology Foresight. Journal of Forecasting, vol. 22, no 2-3, pp. 235-255.

Schwarz J.O. (2008) Introducing a new perspective to developing foresight: Narratives from cultural products. Paper presented at the Annual Conference of the British Academy of Management, 9-11 September, Harrogate, UK.

Smith J.E., Saritas O. (2011) Science and technology foresight baker's dozen: A pocket primer of comparative and combined foresight methods. Foresight, vol. 13, no 2, pp. 79-96.

Tichy G. (2004) The over-optimism among experts in assessment and foresight. Technological Forecasting and Social Change, vol. 71, no 4, pp. 341-363.

van Der Meulen B., de Wilt J., Rutten H. (2003) Developing Futures for Agriculture in the Netherlands: A Systematic Exploration of Foresight. Journal of Forecasting, vol. 23, pp. 219-233.

van Raan A.F.J. (1996) Advanced bibliometric methods as quantitative core of peer review based evaluation and foresight exercises. Scientometrics, vol. 36, no 3, pp. 397-420.

Vecchiato R. (2012) Environmental uncertainty, foresight and strategic decision making: An integrated study. Technological Forecasting and Social Change, vol. 79, no 3, pp. 436-447.

Vecchiato R., Roveda C. (2010) Strategic foresight in corporate organizations: Handling the effect and response uncertainty of technology and social drivers of change. Technological Forecasting and Social Change, vol. 77, no 9, pp. 1527-1539.

Voros J. (2003) A generic foresight process framework. Foresight, vol. 5, no 3, pp.10-21. Available at: https://doi. org/10.1108/14636680310698379, accessed 28.11.2016.

Wilburn K.M., Wilburn H.R. (2011) Scenarios and strategic decision making. Journal of Management Policy and Practice, vol. 12, no 4, pp. 164-178.

Yokoo Y., Okuwada K. (2013) Identifying expected areas of future innovation by combining foresight outputs. Foresight, vol. 15, no 1, pp. 6-18. 